\title{
"Not Wholly Self Culture": The Shakespearean Women's Club, Osage, Iowa, 1892-1920
}

\section{CHRISTINE PAWLEY}

IN 1881 fourteen friends living in a small midwestern townOsage, Iowa - started an informal literary group. Calling themselves the Shakespeare Class, they met once a week in the home of Professor John Rehmann, a local music teacher. The group consisted of three married couples (the Rehmanns, Professor and Mrs. Hardin, and the M. M. Brownes, a prominent attorney and his wife), E. M. Rands, editor of one of the local newspapers, two married women (Clarinda Hitchcock and Mary Johnson), and five single women (Mary Babcock, Maggie Creelman, Ella Owen, Nettie Brown, and Roba Hoag). The group, never numbering more than fifteen, continued to meet for the next eleven years, breaking only for a vacation each summer. By 1890, all of the men had dropped out, and in 1892 the remaining women transformed the informal class into a federated club - part of a nationwide phenomenon, the women's study club movement - that has persisted into the late twentieth century. ${ }^{1}$

Once the women of the Shakespeare Class decided to organize a formal association, they arranged to meet every other Tuesday in members' homes, though they hoped to have a club

As a recipient of a 1995-96 Iowa Sesquicentennial Research Grant, I would like to acknowledge the generosity of the Iowa Sesquicentennial Commission and the State Historical Society of Iowa in providing financial assistance for this research.

1. A Century of Progress: Osage Centennial, 1856-1956, Sage Public Library, Osage, Iowa; Carmella Indra, "The Shakespearean Club," in Leona Montag, Mitchell County History (Dallas, TX, 1989), 61-62.

THE ANNALS OF IOWA 56 (Winter/Spring 1997). (CThe State Historical Society of Iowa, 1997. 
room of their own eventually. ${ }^{2}$ After experimenting for a few months with the name, "Tuesday Literary Club," they finally settled on the title, "Shakespearean Club." From the beginning, members described their activity as mainly literary and their aims in terms of self-education; their purpose, they declared, was "obtaining higher, broader, and truer culture." Members also saw their club activities in terms of group work, however, and they succeeded in conveying this to other members of the local community. In 1896 Shakespearean Laura Eaton wrote in her newspaper column, Woman's Kingdom,

we all feel that instead of walking alone, that we had all the time been walking by our sisters. ... The writer saw a member of our club, one whose life had been spent in an atmosphere of refinement and plenty and sunshine, gazing thoughtfully, and I said 'A penny for your thoughts.' She answered, 'I know for the first time the true mission of the Shakespearean Club.' Not wholly self culture, but it is to enter into, brighten and beautify the lives of all women in this city, who have few pleasures and fewer opportunities. ${ }^{3}$

Thus the Shakespeareans presented their club activities as benefiting not only individual members, but also women in general. In reality, the benefits accrued largely to middle-class women.

Over three decades, the Shakespeareans developed an organization that enabled middle-class women to meet others of similar background and interests, form friendships, and extend social ties. At the same time, members could educate themselves about topics of cultural interest, develop a political awareness, and establish themselves as leaders in the continuing process of transforming Osage from a frontier settlement into a permanent community. Three aspects of the Shakespearean Club in particular illustrate these functions: the context of the club's establishment, the members themselves - their social background, age, religious affiliation, and family situation - and, most importantly, their activities, including both the topics they chose

2. Program of the Shakespearean Club, 1892-93, Shakespearean Club Archives, Osage, Iowa. The Shakespeareans never realized the ambition to have their own room. See below on the "geography of gender."

3. Mitchell County Press, 22 October 1896. 
to discuss and the ways they exercised influence in their local community and in the state. ${ }^{4}$

BY THE END OF THE NINETEENTH CENTURY the "clubwoman" had become a familiar phenomenon in communities of all sizes across the United States. Many American men, too, joined associations at the turn of the century, particularly fraternal orders. Between 1880 and 1900, nearly five hundred new male orders were established; by 1900 , some groups, such as the Masons and Odd Fellows, had well over a half-million members. ${ }^{5}$ In Osage, leading men often belonged to several associations, and the local press claimed that their activities contributed to the work of making Osage a safe, healthy, and prosperous city.

For women, their growing awareness of themselves, and of each other, as belonging to a group with common needs and interests was an aspect of the growing politicization of gender issues during the nineteenth century. As Gerda Lerner has pointed out, from sewing circles and female clubs women learned a self-consciousness "based on the separate interests of women as a group." Estelle Freedman argues that "a separatist political strategy, which I refer to as 'female institution build-

4. I came across the Shakespearean Club records while using public library, church, school, newspaper, and census records to research a cultural history of reading in late nineteenth-century Osage. See Christine Pawley, "Reading on the Middle Border: The Culture of Print in Osage, Iowa, 1870-1900" (Ph.D. diss., University of Wisconsin-Madison, 1996). Records of local communities are rarely found in convenient, centralized archives, but may be scattered among a variety of institutions, such as the city hall, courthouse, churches, and public library. At that time, Shakespearean Club records were kept in a current member's home. I would have had difficulty locating them without the help of the director of Osage's public library. The very existence of the records testifies to a well-run organization; they include not only printed programs, but also manuscript minutes of meetings and actual papers written by one particular member, Mary C. Stacy. By combining this information with census data from manuscript schedules of federal and state population censuses and from contemporary local newspapers, I have compiled a picture of the women of the club at the turn of the century: who they were, their interests, and the role they played in the community as a whole.

5. See Mary Ann Clawson, Constructing Brotherhood: Class, Gender and Fraternalism (Princeton, NJ, 1989), 111; and Stuart McConnell, Glorious Contentment: The Grand Army of the Republic, 1865-1900 (Chapel Hill, NC, 1992), 88. 
ing,' emerged from the middle-class women's culture of the nineteenth century." By associating in informal groups, women learned a concept of "sisterhood" that in turn encouraged a public, political orientation. ${ }^{6}$

Even in the years before the Civil War, some middle-class women had broken out of their "separate sphere," the domestic realm, to form female groups devoted to social reform. Many men and women still adhered to mid-century values of True Womanhood, holding that a woman's unique sphere was the home, where she not only provided for the physical needs and comforts of her husband and children (marriage was the only career thought suitable for women), but also upheld ideals of moral purity and sensibility that a rough and ready masculine world would otherwise neglect. As Mary Ryan reminds us, however, the doctrine of separate spheres "failed to comprehend the elasticity of the boundaries of woman's sphere. In actuality women often stretched the doctrine of the spheres and escaped its confinement in regular and patterned ways. ${ }^{17}$ By the latter half of the century, the number of women taking part in public life in various ways had grown to such an extent that contemporaries had given a name to the phenomenon: they called it the Woman Movement.

Women's reading groups, which can be traced back as far as the mid-seventeenth century, provided solid support for this movement. Theodora Penny Martin describes Anne Hutchinson's attempt in 1635 to form a group for women trying to educate themselves, an effort that male Puritan leaders criticized. For the next two hundred years, women formed other groups that met outside the home. By the 1800s, sewing circles and Bible study groups had become common attachments to churches, urban as well as rural, where women combined their own individual spiritual development with a communal orientation. As changes in print technology and distribution made access to

6. Gerda Lerner, The Majority Finds Its Past: Placing Women in History (New York, 1979), 161; Estelle Freedman, "Separatism as Strategy: Female Institution Building and American Feminism, 1870-1930," Feminist Studies 5 (1979), 512-29.

7. A number of commentators discuss the notion of woman's separate sphere. For a useful summary, see Mary P. Ryan, Womanhood in America: From Colonial Times to the Present (New York, 1983), especially chap. 3 (quote from p. 118). 
printed materials other than Bibles and religious tracts easier, middle-class and working-class women began to take advantage of the more ready availability of books to form reading clubs and lecture groups. After the Civil War, middle-class women began to found such clubs in increasing numbers. The rationale for study clubs was generally that they promoted individual self-improvement rather than collective social or political goals. Perhaps this educational justification seemed less threatening to advocates of the doctrine of separate spheres than overt political action. Nevertheless, during this period, groups of women activists also established nationwide organizations such as the Woman's Christian Temperance Union (WCTU) and the National Woman's Suffrage Association. In 1873 four hundred women met in New York City for the First Woman's Congress of the Association for the Advancement of Woman to discuss the question, "How Can Women Best Associate?"8

Even at the end of the century, however, women's intellectual ambitions were still controversial. Osage inhabitants were often exposed to the "separate spheres" ideology, as male and female newspaper contributors continued to deride women's aspirations to higher education or work outside the home. In 1902 novelist G. B. Burgin wrote in the Mitchell County Press on the subject of the "Intellectual Woman." He described two pictures, a "before" picture of a young and beautiful woman "with clear, thoughtful eyes as yet undimmed" standing "on the threshold of a great library ... her white teeth . . . parted in a dazzling smile, as the demon of intellect beckoned her into the library." The second picture showed the same woman ten years later. Now her face was "furrowed, haggard, careworn; her eyes bleared and dim; her neck, the neck of a vulture. She has lost her youth, her wrapper is in holes, her hair untidy, her mouth ill-tempered, her teeth faulty." ${ }^{\prime 9}$ Such were the dangers for women of intellectual activity.

8. Theodora Penny Martin, The Sound of Our Own Voices: Women's Study Clubs, 1860-1910 (Boston, 1987), 5-6, 9, 14; William J. Gilmore, Reading Becomes a Necessity of Life: Material and Cultural Life in Rural New England, 1780-1835 (Knoxville, TN, 1989), 257; Bruce Laurie, Working People of Philadelphia, 18001850 (Philadelphia, 1980), 33.

9. Mitchell County Press, 22 October 1902. 


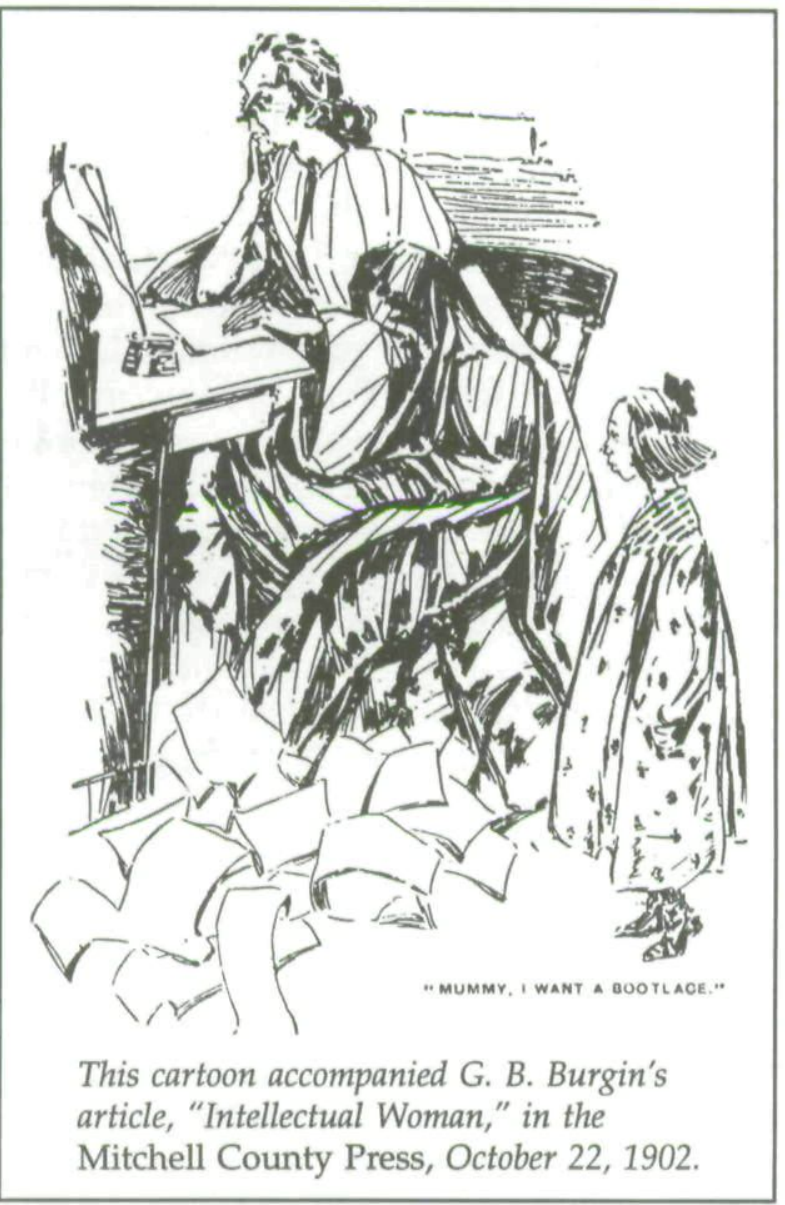

Another Mitchell County Press contributor painted a more sympathetic, though patronizing, picture. "It is the real thing now-a-days for the women to organize clubs, literary in their nature and guaranteed to furnish culture while you wait," wrote "The Pharisee" in 1906. "These club women are mostly women who are too heavy for light amusements and not old enough to stay at home. . . . The average club woman could not give a correct list of the present county officers to save her life, but you ask her who Beowulf was or how Mary Queen of Scots wore her back hair and she will heave a fast one over the plate before you can get the bat off your shoulder." Although the (presumably male) writer attributed political naiveté to club- 
women, he rose above derision: "Some people wonder why women will do these things, but the reason is plain. For once she is neither wife, mother, sister, or daughter, but just plain herself, with an individuality all her own, and she enjoys it to the uttermost. ${ }^{10}$ This Osage writer evidently found clubwomen's activities acceptable on the grounds of individual self-expression, while denying their understanding of local political processes.

Despite ominous warnings and ridicule, late nineteenthcentury women joined associations in large numbers. Many women's clubs started as isolated efforts. Before long, however, women were organizing on a state and national level. The Association for the Advancement of Women held its thirteenth congress in Des Moines in 1885, giving rise to at least two new clubs. In 1890 East Coast activists founded the General Federation of Women's Clubs (GFWC) as a national organization with which local clubs could affiliate. By 1896, the GFWC had grown from the sixty clubs that took part in an organizing meeting in 1889 to 495 clubs representing a hundred thousand women. ${ }^{11}$ The Shakespearean Club affiliated with the GFWC when it reorganized in 1892. In 1897 it also affiliated with the Iowa Federation of Women's Clubs. ${ }^{12}$

THE OSAGE WOMEN who joined the Shakespearean Club were a homogeneous group of white, middle-class, Anglo-Saxon Protestants. Most were married to prominent professional men in the community and were already acquainted through class, kinship, church, or other associational activities. While conflicts of opinion might arise within such a group, these differences were hardly likely to shake the world view of any individual member. ${ }^{13}$ That

10. Mitchell County Press, 18 July 1906.

11. Martin, The Sound of Our Own Voices, 57.

12. Indra, "The Shakespearean Club," 61.

13. Martin, The Sound of Our Own Voices, 70-71. While Martin observes that women's clubs were homogeneous groups composed of white, middle-class, Anglo-Saxon Protestants, she also claims that "the study club provided a social diversity unknown to most women, whose relationships outside the club were determined by kinship and by religious and political sympathies, associations with 'our own kind"' (71). Martin's observation may be true of clubs in large 
world view was shaped as part of the women's experience in the northern Iowa community of Osage.

First settled by whites in the early 1850 s, by the 1890 s Osage was a typical small midwestern town. With a population of only two thousand, it nevertheless played a large part in the life of the surrounding farmland. Not only was it the county seat, but it was also the center of banking, commerce, entertainment, and education for the people of Mitchell County. Dominated by English-speaking Protestants with New England and MidAtlantic roots, Osage institutions promoted middle-class values of hard work, temperance, and individual prosperity. An important feature of the town was the Cedar Valley Seminary, a Baptist institution that combined the functions of high school and junior college. ${ }^{14}$

The Shakespearean Club was just one of many voluntary associations that Osage inhabitants formed in the last two decades of the nineteenth century. A few groups, including some church societies, the Patrons of Husbandry (also known as the "Grange"), and the Good Templars, included both men and women. Many more were segregated by sex. Osage men could belong to fraternal orders such as the Masons, the Grand Army of the Republic, the Knights of Pythias, the Ancient Order of United Workmen, or the Independent Order of Odd Fellows. They could also be members of political parties, businessmen's clubs, and professional or trade associations such as the Stockbreeders' Association. Women could join church-related groups, such as missionary societies or the Universalist Ladies Aid Society; auxiliary groups to fraternal associations, such as the Women's Relief Corps; reform groups, such as the Woman's Christian Temperance Union and Woman Suffrage Society; or women's study groups and reading circles. Reflecting what Mary Ryan calls the "geography of gender," male groups such as the Masons often built a special meeting place or "lodge," while women's

cities, but in a small-town club like the Shakespeareans, there was little diversity of class, religion, or ethnicity among the members. These women's speaking, reading, and writing experiences were not challenged in the club by the presence or contribution of women with radically different social characteristics. 14. A well-known alumnus of the seminary was Hamlin Garland, writer of realistic but unflattering novels about Iowa farm life at the turn of the century. 
groups usually met in members' homes. Lacking personal financial resources, they probably had little alternative, but they also may have felt that domestic space, at least during daytime hours, was under their particular control. ${ }^{15}$

Several reading circles flourished in Osage in the early 1890s, but only the Shakespeareans lasted for more than a short period. This longevity was undoubtedly due in part to early members' devotion. Of twenty-four charter members, nine retained full or associate membership for twenty years or more, while another four did so for fifteen years. Thus, more than half of the original members were still associated with the club fifteen years later. Not every charter member achieved such a record of faithful association, however. Two did not even last until the end of the first year. The first president resigned after the first year. Of the members who replaced the early dropouts, some imitated the long and faithful association of most charter members, but most stayed in the club for only two or three years.

By the end of its first year, the total membership had stabilized at twenty-five. Members saw this number as the maximum that could meet comfortably in a private home. It is an indication of the Shakespeareans' affluence that a group of this size could fit into their "parlors." During the next four years, the group added fifteen new members as the same number dropped out, and a waiting list formed. In July 1894 the club agreed to expand its membership to thirty, and later added an additional membership category - "Associate" - to accommodate existing members who felt unable to continue in full membership. For

15. In Osage, one women's group, the WCTU, did establish a meeting place of its own. In the fall of 1893 the Shakespearean Club experimented with renting the WCTU room, "as it is centrally located," but the arrangement did not last. Mitchell County Press, 14 September 1893. Mary Ryan uses the phrase the geography of gender in Womanhood in America, especially 115 and 211, to describe the movement by women to establish organizations in the public sphere that were nevertheless separate from the public organizations of men. The physical location of these organizations is one aspect of the geography of gender. Gerda Lerner has pointed to women's need for "sex-segregated social space" which "became the terrain in which women could confirm their own ideas and test them against the knowledge and experience of other women." Gerda Lerner, The Creation of Feminist Consciousness: From the Middle Ages to 1870 (New York, 1993), 279. 
the two decades after 1899 , membership in the club was always at full strength, and there was usually a waiting list of women anxious to be elected.

While the membership of the club fluctuated considerably, a core remained active for a very long time indeed, and these, along with key charter members' energy and staying power, held the club together long after other reading groups had disbanded. Two charter members-Mary Johnson and Clarinda Hitchcock - were also members of the first Shakespeare Class in 1881. Both remained active in the club for more than twenty years. Clarinda Hitchcock, thirty-eight years old in 1881, kept up a continuous membership until 1913, when she was seventy. She never held office, although she served on the Topic Committee for three of the club's early years. Mary Johnson's record is even more extraordinary. She was the same age as Clarinda Hitchcock, and probably the two women were close friends, since they shared many activities and had children of roughly the same age. Johnson, too, maintained continuous membership in the club, only withdrawing in 1915 when she was seventytwo. During that time, she was president twice, vice-president seven times, served on the Topic Committee three times, and was the first Federation secretary of the club. ${ }^{16}$

The club must have played a major part in the lives of these longtime members. However, several did not confine their public activities to the Shakespearean Club. Clarinda Hitchcock was secretary of the school board from 1889 to 1895 . She was one of the first two women members of the Sage Public Library Board in 1895 (the other was Mary Johnson), and remained on that board until 1903. A former student at the Cedar Valley

16. I have compiled biographical information on Clarinda Hitchcock, Mary Johnson, and other Shakespeareans from a number of sources. Shakespearean Club annual programs contain information on details of their club membership. By far the richest source of information on other aspects of their lives has been the local press - the Osage News and Mitchell County Press. These newspapers printed weekly columns of "Local News" in which they provided short accounts of the activities of the town's leading citizens during the previous week. They also occasionally printed longer accounts of meetings held by groups such as the WCTU. Other biographical data come from federal and state censuses, minutes of the Sage Public Library Board, and catalogs of the Cedar Valley Seminary. 
Seminary in the 1870 s, she was treasurer of its alumni association. She was also a member of the Woman's Christian Temperance Union and a local Chautauqua circle, and was prominent in the Woman Suffrage Society, hosting many of its meetings during the 1890s. All of this activity occurred while she was also contributing to the work of the family farm, raising two daughters and a son, and helping care for her elderly mother. Laura Eaton, wife of an attorney and state politician, was another indefatigable worker. In addition to her twenty-four years' association with the Shakespeareans, she was active in many of the same organizations as Clarinda Hitchcock - the WCTU, the Havergal Chautauqua Circle, and the Woman Suffrage Society. She was also editor of a women's column in the Mitchell County Press and a member of the Sage Public Library Board, serving as president in 1899 . Women such as these do not at all fit the stereotype of the women's club member filling in idle hours with desultory reading, while her male counterpart wheeled and dealed among his downtown cronies at lodge meetings.

In fact, the social composition of the Shakespeareans matched that of other dominant groups in Osage's social structure, such as the City Council, the Masons, and the Board of Trade. Whereas five of the ten women in the original Shakespeare Class were single, members of the new Shakespearean Club were almost all married - mostly to men who occupied prominent positions in Osage society. Of thirty-two members in the 1890 s whose husbands' occupation is known, twenty-one were wives or daughters of the most affluent and prominent men of the town - bankers, attorneys, clergymen, physicians, and successful businessmen. One (Lucretia Deering) was the wife of a U.S. congressman; later she founded the Osage chapter of the Daughters of the American Revolution. Nine more came from less prominent, but still solidly middle-class families. Ella Hastings and Jeannette Katz, for example, were married to merchants. Frances Stacy and Alice Fisk were schoolteachers. Only two-Clarinda Hitchcock and Lucy Hawley — came from farm families. Neither, however, could be categorized as anything but middle class: Hitchcock was the daughter of a judge (a founder of the town and a well-known member of the bar), while Hawley was the mother of a prosperous jeweler. 


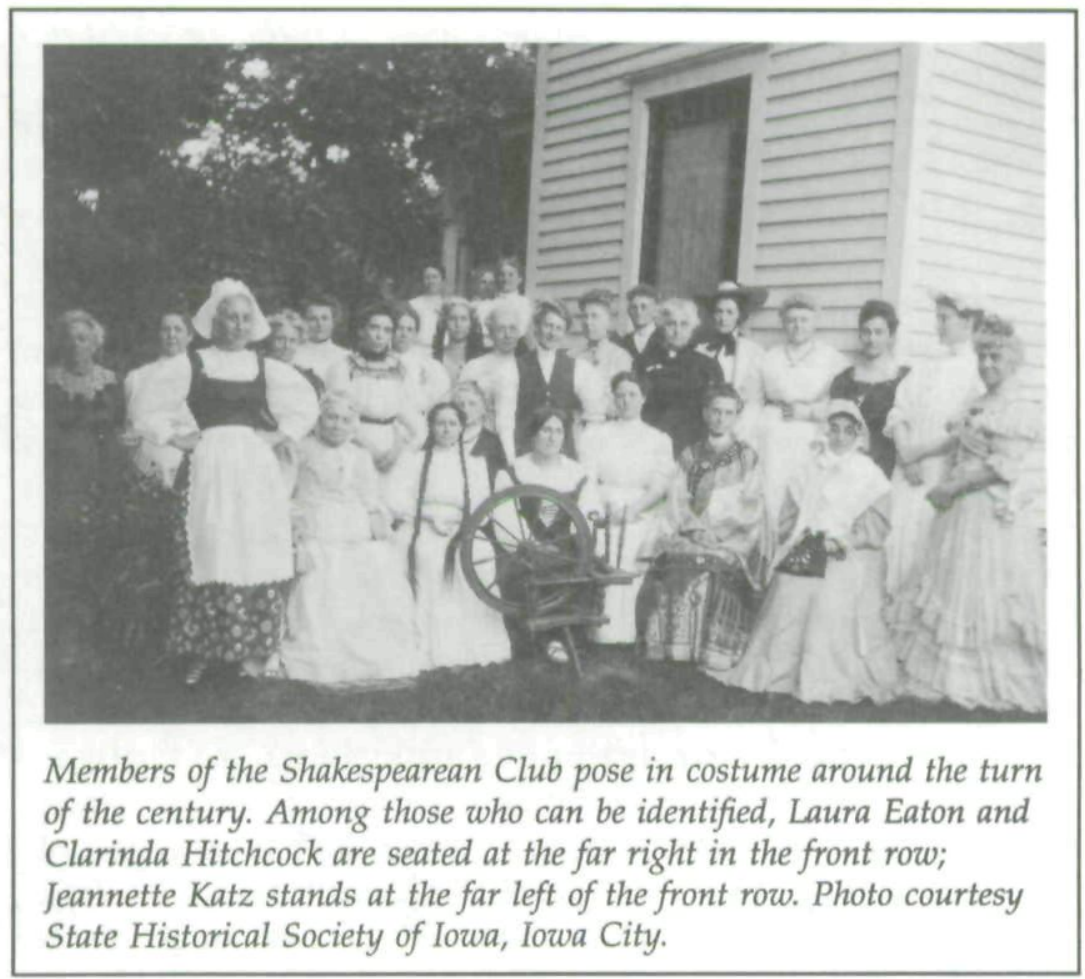

Newspaper reports of the annual Shakespearean banquet promoted the image of club members as well-to-do and influential. In 1910 members held their banquet in the Congregational church hall, where "three long white draped tables with their array of silver and china extended a mute but appealing welcome to all." The food was elaborate: "six well-chosen courses" started with fruit cocktail and ended with ice cream. After the "dainty viands" had been consumed, the evening was spent in "witty, learned and well handled discourse."17 Thus, material prosperity reinforced moral and intellectual "uplift."

Of the thirty-one early members whose religion is known, almost all were mainstream Protestant-mostly Congregationalist. One, however, was Jewish (Jeannette Katz), and another (Ella Hastings) took the highly unusual step of listing her reli- 
gion as "none." ${ }^{18}$ No early members were Catholic or Lutheran, despite Osage's sizable population of middle-class Catholic women (and much smaller population of middle-class Lutheran women). The women's Protestant ethic, which led them to believe that Christians should strive to make the world a better place, also accorded with the club's self-improvement and social interventionist aims and ethos.

Of the thirty-five club members whose birthplace is known, all but one were native-born Americans; Sarah Wilcox, wife of a Baptist preacher, was born in England. Fifteen came from eastern states, including New York, Pennsylvania, Vermont, and Maine. Seventeen (including all of the younger members) were midwesterners, including nine born in Iowa. Two women born in Kentucky (Louise Abernethy and Louise Fay) were, like many other members, old enough to have had some recollections of the Civil War.

Yet the Shakespeareans do not fit historian Karen Blair's characterization of most study club women as older married women whose children were no longer their responsibility. ${ }^{19}$ Most members were middle-aged, the majority in their thirties, forties, and fifties. Nineteen of thirty-six married members had young children or teenagers to care for. Jeannette Katz had three, her youngest being ten years old in 1892. Ella Lapham also had three: in addition to nine-year-old Burnett and four-year-old Joyce, she had one-year old Percy when she undertook to serve on the Topic Committee in 1892. Two wives of clergymen had the heaviest responsibilities at home. By 1895, Lilian Gist (Congregationalist) had six boys and a girl, including two born in 1893 and 1895 when she was playing a full role in the club. Sarah Wilcox (Baptist), who joined the club in 1894, had five children, including twin boys born in 1892 . While they undoubtedly had some paid household help, only three of the mothers

18. Of the fifty-eight Osage residents who declared themselves as having no religion in the 1895 census, only eleven were women.

19. Karen J. Blair, The Clubwoman as Feminist: True Womanhood Defined, 18681914 (New York, 1980), 63. The Shakespeareans more closely fit Janice C. Steinschneider's depiction of clubwomen as "middle-aged married women leading ordinary domestic lives." Janice C. Steinschneider, An Improved Woman: The Wisconsin Federation of Women's Clubs, 1895-1920 (Brooklyn, NY, 1994), 4. 
had live-in domestic servants. Probably many Shakespeareans employed domestic workers who did not live with the family, but few had access to permanent help on a twenty-four-hour basis. In any case, even for women with full-time domestic help, housework was still a major activity. As late as 1914, according to Ruth Schwartz Cowan, the average time spent on housework by an affluent middle-class woman with domestic servants was fifty-six hours per week. ${ }^{20} \mathrm{It}$ is hard to reconcile these figures with Blair's claim that clubwomen's responsibilities in the home had diminished with age or the availability of domestic help and that the club mainly functioned to fill spare leisure hours.

THE WORK OF THE CLUB could consume a sizable amount of time for its most active members. The club was run by five main officers; along with the president, vice-president, secretary, and treasurer, the club also appointed a Federation secretary, whose duties consisted mainly of carrying on correspondence with the General and State Federations. The Shakespeareans seem to have made a systematic attempt to integrate new members into the club by placing them on the Topic Committee (or maybe this was a job that old-timers were only too glad to pass on to unsuspecting newcomers). In the first year, as many as seven members served on the Topic Committee, perhaps because that was the most daunting task facing the newly formed club. The following year, that number fell to five, and after that to three. Occasionally, the key officers also served on the Topic Committee. ${ }^{21}$

In general, offices rotated unsystematically among a small elite. Mary Johnson was not the only member to hold office time and time again. Jeannette Katz was the first vice-president and was later vice-president two more times, president twice, secretary once, and member of the Topic Committee three times. Ella Hastings was secretary for the first five years of the club's

20. Ruth Schwartz Cowan, More Work for Mother: The Ironies of Household Technology from the Open Hearth to the Microwave (New York, 1983), 159.

21. Printed annual Shakespearean Club programs and minutes of the club's meetings are the main sources of data about club membership and study activities. 
existence and was Federation secretary twice, treasurer once, and member of the Topic Committee twice. Amelia Lohr, who was a member of the club for twenty years, was president, vicepresident, and Federation secretary, and served for five years on the Topic Committee. On the other hand, Clarinda Hitchcock served on the Topic Committee for the first four years, but never again held office in her twenty-two years of full membership. Perhaps she recognized that she was too fully committed elsewhere. Laura Eaton, too, was only on the Topic Committee once and Federation secretary once. Few members went through several years of membership without serving at least once on the Topic Committee, and for most, that was the extent of their commitment.

Shakespeareans allocated topics for study and presentation in a variety of ways. At the beginning, they experimented with organizational procedures in order to find those best suited to their purposes, feeling their way with the unfamiliar demands of formal organization. However, they were not afraid to make adjustments when procedures did not work well. In the first year, topics were distributed in an extremely uneven manner. Whether from lack of confidence or from unwillingness to shoulder their fair burden, some members prepared only one or two topics, while others took responsibility for several. Of those who continued their membership throughout the whole year, everyone prepared at least one, and in the case of Margaret Sweney Dailey, that was all she did. Lucy A. Blackman and Mate E. Libby prepared two topics, while Lilian Gist prepared three. On the other hand, Jeannette Katz took part in eight, and Amelia Lohr, seven. The majority of members participated in five.

This inequity did not go unnoticed, for in the next year the club adopted a strict alphabetical rotation. As a result, everyone was responsible for at least four topics, while those at the beginning of the alphabet (including Blackman and Dailey) ended up with five. However, members may have perceived this system as too rigid, for in the third year of the club's existence, yet another method was tried. Far fewer topics were attempted. In addition, the club adopted a system of allocation that combined elements of rotation and choice. During the first run-through of topics, everyone took a turn; then members were asked to 
undertake a second topic. While everyone thus took at least two turns, and some took three, several more prominent members (Clarinda Hitchcock, Jeannette Katz, and Annie Sweney) took four. In the following two years (1894-95 and 1895-96), a similar system seems to have been in operation. In 1894-95 everyone prepared three topics, while most did four. Again, two leading members (Clarinda Hitchcock and Amelia Lohr) undertook five. In 1895-96 the number of topics was again sharply reduced. Everyone took two topics, while about half took three. No one took more than three.

This analysis suggests that those who carried the burden of the program were leading members of the club, and that they perhaps dominated the proceedings. Women who bore more than their share of the burden of preparing topics (or alternatively occupied more of the limelight) included Caroline Decker, Lucretia Deering, Clarinda Hitchcock, Mary Johnson, Jeannette Katz, Amelia Lohr, and Annie Sweney. Except for Caroline Decker, all played key roles in other Osage organizations - sometimes in several others - and constituted an interlocking directorate of Osage groups. ${ }^{22}$ However, members were aware of the danger of allowing meetings to be dominated by a few, and insisted that everyone should have the chance to participate. "Each member is made to feel that she may have a part in the programme of each meeting," declared the Mitchell County Press in 1895. "There is always an opportunity for each or any member to contribute her mite that may add interest to the subject under discussion." ${ }^{23}$

Club minutes show that administrative details absorbed a large proportion of meeting time. Membership was always an important topic; new members had to be proposed and voted upon before an invitation could be extended. Even small expenditures of a dollar or two, related to the printing of programs or banquet arrangements, required majority approval and were

22. According to Mary P. Ryan, this was a common pattern at a national level among organized women, who, "between 1890 and 1920 . . . built a national organizational network that was nearly as sophisticated in its own way as the corporate business world." Ryan, Womanhood in America, 204.

23. Mitchell County Press, 17 October 1895. 
the cause of much discussion. Every item, however small, was dealt with according to rules of parliamentary procedure-a time-consuming device, but one that helped ensure that a small elite did not entirely arrogate decision making to themselves.

Frequently, opportunities arose for members to show support for each other through expressions of condolence or congratulation. Almost weekly, members extended "love and sympathy" to those whose households were stricken with illness. In a period of a few weeks at the end of 1901, members sent flowers and congratulations to Nellie Taylor on the birth of a boy, and condolences to Ella Lapham on the death of her young son, Burnett, and to Jessie and Cora French on the death of their mother. ${ }^{24}$ After the turn of the century, the club adopted the practice of presenting silver spoons to retiring long-term members. In 1913 the club also presented a silver tablespoon to Jennie Bartholomew on the occasion of her wedding to Arad Hitchcock (son of Clarinda Hitchcock). This marriage was very much a club affair; the Hitchcocks invited the whole club to the wedding reception, held at the Universalist church. ${ }^{25}$

Once a year, the Shakespeareans held a Halloween "dramatic entertainment." In 1902 it was held "at the beautiful home of Mrs. Geo. Chandler" (wife of the county school superintendent). The Chandlers' house must indeed have been impressive; not only could the Shakespeareans erect a stage complete with curtain, but they began their program with an actors' procession "down the stair and stately hall." The entertainment included scenes from Cyrano de Bergerac, recitations from Macbeth, and tableaux depicting paintings. The 1893 Columbian Exposition at Chicago had evidently exercised an influence on the choice of subjects. The "Tableau - 'Madame Granseon' by Courtois was indeed lifelike and full of expression," the Mitchell County Press correspondent wrote enthusiastically. "You undoubtedly remember seeing the same at the White City, in the French section." Later in the proceedings, serious presentations were set aside in favor of games such as "Bobbing for the Apple, Swinging

24. Minutes, 24 September and 17 December 1901 and 14 January 1902, Shakespearean Club Archives.

25. Minutes, 11 February and 8 April 1913, Shakespearean Club Archives. 


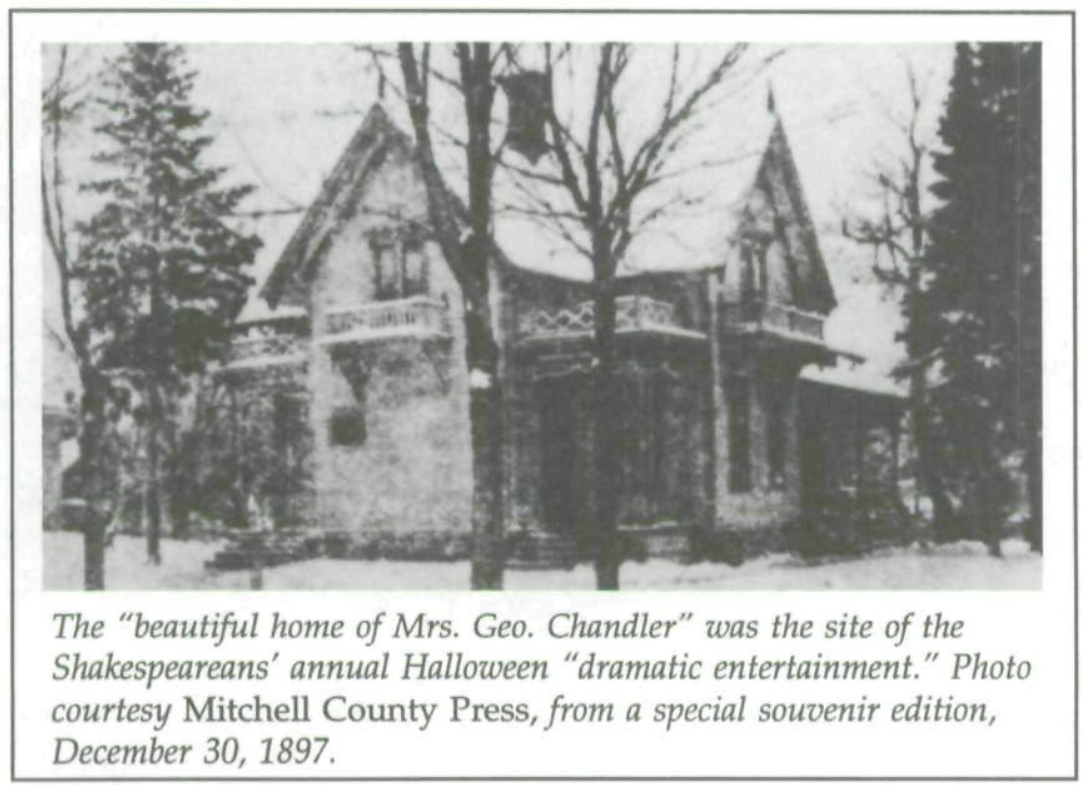

the Apple, [and] Blowing out the Candle." ${ }^{26}$ As the newspaper account made clear, with its unexplicated references to art and literature, an aside about the "trick of the electric lights," and its assumption that readers would be familiar with the 1893 Exposition, Shakespeareans inhabited a prosperous middle-class world, characterized by a pursuit of high culture in surroundings of comfort and affluence. The success of their activities in the community depended on their position in that world.

THE CLUB'S ACTIVITIES encompassed a wide range of endeavors, but they generally fell into one of three categories: cultural education, the discussion of political issues, and direct involvement in promoting political and social causes. Clearly, these activities extend beyond the self-improvement culture usually associated with women's study clubs. The women of the Shakespearean Club sought to provide effective leadership for their community and - in cooperation with other Federated Women's Clubs - their state. 
The club played an especially important educational role. Between 1870 and 1900 women's participation in higher education expanded dramatically. In 1870 less than one percent of eighteen- to twenty-one-year-old women were enrolled in college. By 1900 , that number had quadrupled..$^{27}$ Even in the 1890 s, however, for women like the Shakespeareans, a college education was out of the question. Some Shakespeareans sent their daughters to college-Helen Hitchcock attended the University of Chicago, for example, while her sister Augusta went to Lombard College-but the founding members themselves had missed such opportunities. As Theodora Penny Martin has argued, study clubs fulfilled an educational function for those women for whom a college - or even a high school-education was not a possibility. ${ }^{28}$

The education that the Shakespeareans provided for themselves reflected curricular conventions of the day. In the beginning, British and American history predominated, along with writers who formed part of the current literary canon, such as Tennyson, Longfellow, and Washington Irving. While these were mostly male, Shakespeareans also included women writers, such as novelist George Eliot, poet Elizabeth Barrett Browning, and abolitionist author Lydia Maria Child. Later, they branched out to the literature of other European countries. The year 1900 to 1901 , for example, was devoted to the study of Dante; in 1901 to 1902 the club concentrated on German literature and history, with particular emphasis on Goethe's Faust; and in 1902 to 1903 members focused on French and Russian literature and history. Not surprisingly, Shakespeare's plays were often on the program, as were religious topics.

In the early years, weekly programs were set out in considerable detail and contained as many as ten separate items. It seems as though club members could not cram enough into their meetings. A typical program included a couple of readings from literature, at least one paper on a literary or historical topic, a "Discussion" led by one member, and a "Conversation" led by

27. Barbara Miller Solomon, In the Company of Educated Women: A History of Women and Higher Education in America (New Haven, CT, 1985), 64.

28. Martin, The Sound of Our Own Voices, 2-3. 
another. Yet another member would give a "News Summary," and further opportunities for general participation arose in sessions on "Extemporaneous Speaking" and "Quotations." The afternoon's activities left little room for passive listening; everyone was expected to speak up and express an opinion.

Members especially emphasized extemporaneous speaking, recognizing that women traditionally had little opportunity to develop the art of speaking in public without preparation. "Every member ought to accustom herself to speak extemporaneously," wrote a Shakespearean newspaper correspondent in 1897. "Talent sometimes develops where it is least expected. It is not necessary that we should be born with talent. Talent comes with practice. ${ }^{29}$ Speaking in public was not a traditional female activity, even for educated women. Even at a place as receptive to women students as Oberlin College, for example, antebellum female graduates were not permitted to read aloud their own commencement orations until $1857 .{ }^{30}$ The Shakespeareans' emphasis on public speaking, therefore, represented a significant and conscious break with the traditions of True Womanhood.

As the years went by, programs became less and less specific in setting out the plan for the afternoon. By the turn of the century, the number of separate items had been halved, reduced to a roll call, a couple of papers or short sketches, and a conversation or debate. A few years later, programs listed only a single topic and the names of the three or four members responsible for that afternoon's activities. Each spring, club members chose a theme for the following year's focus. Initially, these were not made explicit in the program, but could be deduced from the list of each week's activities.

During the first three decades, Shakespeareans tried a variety of formats for their meetings. For several years, they subscribed to entire courses of study published by such organizations as the University of Chicago Extension and the American Institute for Sacred Literature. However, these imports left little room for expression of club members' individual interests, and

29. Mitchell County Press, 14 January 1897.

30. Solomon, In the Company of Educated Women, 29. 
in time the club moved toward combining set courses of study with discussion of topics suggested by members.

Although a unifying thread is discernible in the topics covered, the early programs give the impression of a medley of unconnected items. For example, on February 28, 1893, the afternoon began with quotations from Charles Kingsley, and proceeded to papers on "The Experiment of Confederation" and "Idealism and Realism in Fiction," followed by a presentation on the World's Fair, an essay on "The Fate of Inventors," a debate on the subject, "Resolved that private tuition is better than class teaching," and a News Summary. ${ }^{31}$

Contemporary critics ridiculed this eclectic approach. Sinclair Lewis describes his Main Street "Thanatopsis Club" as studying "Men and Women of the Bible" one year, "all of European literature" in the next, followed in the third year by "Furnishings of China." Subsequent historians, too, have been critical; Anne Firor Scott describes the groups' study practices as "superficial flitting from topic to topic." ${ }^{132}$ However, a certain exuberance emerges from this energetic grappling with several subjects simultaneously. No one could accuse the Shakespeareans of faint-heartedness; few subjects were too large or complex for them to tackle.

Program design was also probably influenced by expediency. The Topic Committee determined the content of programs several months ahead of the scheduled meetings; in their efforts to balance members' individual suggestions with the need for a coherent theme they may have produced what seemed to outsiders a hodgepodge of unrelated ingredients. As time went on, they gradually reduced their expectations to a more realistic level. They were also more explicit about sticking to a single subject. In 1896 they started to identify the year's theme on the front page of their programs; in that year they chose "English history and literature during the reign of the Stuarts." The following year they picked "English history and literature during the reign of the House of Hanover." The year after that, rather than

31. Program, 1892-1893, Shakespearean Club Archives.

32. Sinclair Lewis, Main Street (New York, 1980), 124; Anne Firor Scott, Natural Allies: Women's Associations in American History (Urbana, IL, 1991), 115. 
follow up what was in danger of becoming a multi-year project, they changed course completely, and chose simply "General topics: travel and sociology."

Even in the more structured years, however, the Shakespeareans made sure that topics of personal concern or expertise found a place in the program. On several occasions Jeannette Katz inserted presentations based on her interests and experience. In 1899, for example, she gave an unscheduled talk on "the Dreyfus affair and its effect on the condition of the Jews in Europe." As one of only two adult Jewish women living in Osage at the time (the other was her elderly mother-in-law, who spoke only German), she had doubtless followed the controversy more closely than most of her neighbors. In March 1901, perhaps drawing on the experience of sharing a household with her mother-in-law, she gave a presentation on "The German hausfrau." She also held the club to a high procedural standard. In 1900 the minutes record that "Mrs. Katz criticized the omission of parliamentary rules as well as mispronounced words." ${ }^{33}$

The Katz family was firmly situated in Osage's middle class. Ben Katz was a popular and respected businessman, and the three Katz children were models of good behavior and accomplishment, often performing violin solos and helping serve refreshments at public events. Even though they were the only Jewish family in Osage (a brother had moved on to Washington State in the early 1890s), they managed to maintain ties with Iowa's Jewish community. When Ben's mother died in 1904, the funeral service was conducted by "Dr. Sonnenschein of Des Moines," and the Osage News wrote that Helene Katz "was an earnest and consistent believer in the Jewish faith." ${ }^{34}$ How Jeannette Katz reconciled her Jewish faith and identity with her involvement in an overwhelmingly Christian club is hard to elicit from the records. However, she seemed to use her Jewishness as the basis of a sort of specialized expertise. In 1907-8, the club adopted as one of its themes for the year

33. Minutes, 26 September 1899; Program, 1900-1901; Minutes, 25 September 1900, Shakespearean Club Archives.

34. Osage News, 1 December 1904. 
"Foreshadowings of the Christ," an outline compiled by the American Institute of Sacred Literature focusing largely on biblical texts shared by Jews and Christians. According to the minutes, in January the topic for study was "the scheme of Deliverance." On this occasion, "Mrs. Katz gave an exposition of the scheme of deliverance from the viewpoint of Judaism"; a discussion followed her talk. ${ }^{35}$

Shakespeareans' activities also reflected some curricular innovations. In 1894 Osage women formed a "Ladies Gymnasium Association," and in 1895 the Shakespeare Club debated the topic, "Resolved, that physical culture for women is of more importance than literary clubs." Shakespearean Linna Goodall was a key figure in promoting this development. After she gave a talk on the subject of "Physical Culture" in 1900, members pushed back their chairs and performed some exercises. The WCTU and other women's groups supported "Physical Culture," along with dress reform, as encouraging greater equality between the sexes. In the 1890s college women also enthusiastically took up athletic activities. As Joseph Gusfield points out, because "taboos of modesty made it immoral to dress in ways which enabled the woman to exercise," "dress reform and physical exercise were turned into symbolic acts of rebellion and liberation." For the Shakespeareans, however, the experience was more than a statement of principle. The secretary recorded that the exercises were "evidently enjoyed," "for a motion was made that Mrs. Goodall be appointed leader of Physical Culture and that we have some exercises at each meeting." ${ }^{\prime 36}$

Another curricular movement at the turn of the century introduced scientifically based courses in home economics to colleges all over the United States. ${ }^{37}$ This development did not escape the notice of the Osage Shakespeareans. In December 1896 they debated whether "Unsanitary food and clothing have contributed more to the degeneracy of the human family than

35. Minutes, 7 January 1908, Shakespearean Club Archives.

36. Mitchell County Press, 11 October 1894; Joseph R. Gusfield, Symbolic Crusade: Status Politics and the American Temperance Movement (Urbana, IL, 1966), 90; Minutes, 11 September 1900, Shakespearean Club Archives.

37. Solomon, In the Company of Educated Women, 85-86. 
the use of alcohol and narcotics," and in March 1901 they devoted an entire afternoon to discussing definitions of housekeeping and homekeeping and the "Five Food Principles." Later, these occasional forays into domestic topics broadened into a systematic study of what had become an accepted academic discipline. Members gave talks on "Domestic Science" or home economics in September 1908, February 1914, and September 1914, and the club adopted domestic science as a theme for the entire year in $1912-13 .^{38}$

NOT ALL of the Shakespearean Club's educational activities were individualistic efforts at apolitical self-improvement, however. Club members were also anxious to learn about contemporary political issues, along with more conventional literary and historical subjects, and they used the club as a forum to air their own opinions. Members expressed political awareness principally in two ways: through the formal structuring and publicizing of their activities and through the selection of political issues for discussion, study, and debate.

In drafting a written constitution, holding elections for office, and adopting Mrs. Shattuck's Manual of Parliamentary Law, Shakespeareans acknowledged that adhering to technical procedures enhanced the club's legitimacy and established a claim to public standing. Leading Shakespeareans also displayed their desire for public acceptance by ensuring that newspapers reported club activities. Notices of forthcoming meetings of the club often appeared in the local news columns, and Shakespeareans made a practice of inviting editors and their wives to their biennial banquets. ${ }^{39}$

They also realized the need to establish links with women's clubs in other communities. In the fall of 1892, they invited Mrs. L. C. Brooks, president of the "Thirteen Club" of Manchester (a similarly sized town in northeast Iowa), to talk about the advantages of becoming a "Federated Club," that is, a member

38. Programs, 1896-1897, 1900-1901, 1908-1909, 1912-1913, 1913-1914, 19141915, Shakespearean Club Archives.

39. Minutes, 5 April 1904, Shakespearean Club Archives. 
of the General Federation of Women's Clubs. ${ }^{40}$ Initially, the GFWC was an alliance of study clubs, but it soon became clear that some founders of the federation, including Jane Croly and other members of the well-known Sorosis Club of New York, wanted to steer the activities of the clubs away from self-education and in the direction of political activism. At a council banquet in 1891, Croly demanded, "Is there not room in the clubs for outlook committees, whose business it should be to investigate township affairs, educational, sanitary, reformatory and all lines of improvement . . . in the schools, in the streets, in the planting of trees, in the disposition of refuse?" In 1896 the GFWC changed its constitution to allow nonstudy clubs to join, and some leaders started to urge study clubs to adopt more public concerns. ${ }^{41}$

The influence of the GFWC probably encouraged the Osage women in their quest to become knowledgeable about political, economic, and social issues, and confirmed their resolve to include such topics on their study agenda, along with more literary subjects. From the beginning, Shakespeareans included political issues in their club discussions. During their very first year, Lucretia Deering (wife of a U.S. congressman) led a discussion of "The Labor Problem," and in May 1894 Laura Eaton (whose husband was a lawyer) gave a presentation on "Property rights of married women." In the next few years, income tax, bimetallism, labor unions, unemployment, and free trade all arose as subjects for study and debate.

Formal papers were the staple of club meetings, but other formats were also popular. Debates were especially useful for addressing political topics. Initially, the subjects chosen were generally defined as falling in the women's "sphere," such as "The work of the outside world unfits a woman for home duties." Later, programs included more general political topics, such as "Will the labor disturbance of 1894 result in good?" and "Is competition an evil?" Later still, members debated whether or not

40. Program, 1892-1893, Shakespearean Club Archives.

41. Steinschneider, An Improved Woman, 7; Jane Croly, quoted in Margit Misangyi Watts, High Tea at Halekulani: Feminist Theory and American Clubwomen (Brooklyn, NY, 1993), 32. 
"The people of India would be morally justified in overthrowing the British Government in India," and "The Government should own railroads, telegraphs, telephone etc." In 1897-98, despite the adoption of "English History and Literature during the reign of the House of Hanover" as a general theme for the year, members also debated a series of political issues, including "The Referendum is practicable and should be become part of the Constitution," "Sugar: its bearing upon Cuba, Hawaii and Politics," and "Our higher Educational Institutions should be maintained at public expense."

One general topic dwarfed all others in emphasis: the role of women in society, in particular, women's franchise. Much of the Shakespeareans' activity can be more readily understood in light of this preoccupation. Members repeatedly focused on women's political and economic rights and status: the right to vote, to own property, and to custody of their own children, and the position of women in the labor force. "How much business knowledge does a woman need and how shall she obtain it?" asked Jeannette Barrett in an informal discussion in 1893. A few weeks later, Barrett published her thoughts in the Mitchell County Press, calling for more finance education for women, particularly so that property-owning women could manage their own affairs. Arguing for equity as much as utilitarian value, Barrett expressed a sense of injustice and a resolution to improve the legal standing and educational opportunities of the next generation of females. "There is a general business education which is every girl's right," she insisted. "All parents expect their sons to become familiar with business ways.... To be sure he may make a miserable failure but then he has had his chance. His sister all this time has had no idea of values. ${ }^{\prime 42}$

Women's enfranchisement arose again and again as a topic for discussion, debate, or formal presentation. In 1910 Jennie Bartholomew gave a paper on "Woman's Suffrage" that the local press quoted extensively. Bartholomew held a unique position in Osage society. She was young (in her early thirties), at the time still single and living with only her fifteen-year-old sister for company. But most significantly, she was also the recently 
appointed full-time pastor of the Universalist church - an almost unheard-of position for a woman at the time. ${ }^{43}$ However, she apparently broke the stereotype of the bluestocking female, too preoccupied with intellectual matters to pay proper attention to her appearance. "If there was a woman present [at the meeting] with a tiny bit of prejudice against one of their own sex occupying so public a place as the pulpit of a church," rhapsodized the Press, "it must surely have been dissipated by the winsome, womanly and eloquent speaker of the afternoon." The Press was in no doubt as to Bartholomew's effectiveness as a public speaker. "She held the rapt attention of all present during the whole of her address and left many a strong argument in favor of the cause which is so dear to her." As the Press summarized these,

Women want to be women always, they don't want to be men. The only reason they ask for the ballot is because they want justice. ... Men and women are equals intellectually and morally. But as the laws now stand in many states the woman suffers first and more keenly than the man. ... It is impossible for a woman these days to buy a spool of thread, a quart of milk or a drink of water without coming in touch with politics as law. Then why should she not have a hand in framing those same laws? It is said by those not in favor of woman's suffrage that a woman can control the ballot by her influence, but Miss Bartholomew clinched that argument with "Why not use both your influence and your ballot." ${ }^{\prime 44}$

Jennie Bartholomew held the most public position of any woman in Osage, but other publicly involved women also used the Shakespearean Club as an arena to explore political issues. Two months after Bartholomew spoke on woman suffrage, Flora May Tuttle, married with two children, raised the question of child labor. In addition to her Shakespearean membership, Tuttle was heavily involved in Baptist church affairs, corresponded with politicians in Washington, D.C., and almost single-handedly

43. Cynthia Grant Tucker does, however, profile a group of women who were Unitarian and Universalist ministers in communities in Iowa and surrounding states around the turn of the century in Prophetic Sisterhood: Liberal Women Ministers of the Frontier, 1880-1930 (Boston, 1990).

44. Mitchell County Press, 9 February 1910. 
founded an Osage naturalist club that later bore her name. ${ }^{45}$ She also felt passionately about social injustice. Her paper on "The Child Labor Problem," which the Mitchell County Press published in abridged form, was carefully researched and contained detailed suggestions for social action as well as an analysis of the problem's causes. Curiously, among these, she pointed to the "multiplication of societies, clubs, lodges, etc., which take the parents away from home or absorb their interest to the exclusion of their duty to their children," apparently unaware of the irony implied in her accusation. She called for improvements in children's education and the enactment of compulsory schooling, a cause the Iowa Federation of Women's Clubs (IFWC) actively supported. ${ }^{46}$ Linking these solutions to women's enfranchisement, she concluded, "What the club women of Maine have done for the children in that state Iowa women can do. I believe that it would come inside of a year if we had woman's suffrage, and made a strong campaign on this issue. ${ }^{\prime 47}$

Conservation, another favorite cause of the IFWC, also arose frequently. ${ }^{48}$ Two weeks after Bartholomew's presentation, Augusta Knowlton (school board secretary) and Wilma Benedict (teacher) presented a joint paper on "Conservation Problems" that warned of the consequences of American profligacy with natural resources. ${ }^{49}$ In March 1913 Mary Stacy, a merchant's wife in her mid-sixties and secretary of the public library's board of trustees, tackled the subject of conservation in a highly rhetorical debating speech on the proposition, "Resolved that government should assume control of all Natural Resources." "Are we satisfied with the present condition of our Natural Resources?" she demanded. "Have the state laws and

45. The Archives of the First Baptist Church, Osage, contain a collection of scrapbooks compiled by Flora May Tuttle.

46. See Carroll Engelhardt, "Compulsory Education in Iowa, 1872-1919," Annals of Iowa 49 (1987), 67, 70-71, 74.

47. Mitchell County Press, 6 April 1910.

48. See Rebecca Conard, "Hot Kitchens in Places of Quiet Beauty: Iowa State Parks and the Transformation of Conservation Goals," Annals of Iowa 51 (1992), 449-53; and idem, Places of Quiet Beauty: Parks, Preserves, and Environmentalism (Iowa City, 1997), 26-30, 78-84.

49. Mitchell County Press, 23 February 1910. 
management proved efficient in conserving the Natural Resources within their boundaries? Should the Federal government assume control of all Natural Resources?" In her answers, this middleclass merchant's wife employed strong populist rhetoric to advance progressive solutions. "Our industries [are] firmly barbaric," she argued. "Corporate greed of course is the cause. The moving powers would incorporate the very atmosphere which we breathe if they could. . . Everything is now measured by the power of money.... The fat boys are making the air vibrant with their howls against any government interference." These "grabbers" of timber, water, and mineral rights were "trying to hide behind states' authority and hypocritically wail against the usurpation of national authority." The states, she feared, were quite unequal to the task of protecting their natural resources. Citing examples from Oregon, Washington, and Minnesota, she particularly criticized Iowa's neighbor, describing its land policy as "inadequate, inefficient, wasteful and vicious in its operation." The solution was obvious. Quoting Gifford Pinchot, Stacy concluded, "The common experience of all countries has proved that only such Forests - and this will apply to all Natural Resources - as are owned or controlled by the Government can be depended on for future supply." 50

STACY'S VIGOROUS SPEECH and the papers of her fellow club members demonstrated an awareness of current political issues that gave the lie to the common charge that clubwomen were politically ignorant and indifferent. Their awareness had already translated into practical action. From the turn of the century onward, the clubwomen gradually extended their activities outside their twice-monthly meetings. They began to correspond with other clubs and with state and national legislative representatives. They adopted causes and began to lobby. In 1909 they helped the Woman Suffrage Society defray the cost of petitions, and in 1913 they wrote to their state representative and senator

50. Shakespearean Club Archives. In 1910 Gifford Pinchot had been dismissed by President Taft from his position on the National Forest Commission for criticizing federal administration of Alaskan coal lands, and in 1912 he had joined Theodore Roosevelt in forming the Progressive Party. 
in support of bills concerning widows' pensions, the women's reformatory, pensions for teachers, woman suffrage, and inspection of women's factory work conditions, as well as water conservation, flag protection, playgrounds, and parks. ${ }^{51}$

In their own community they became even more active. Mistreatment of animals, tobacco use in public, and expectoration on the sidewalk incensed them. They repeatedly contacted the mayor and city council about enforcement of the expectoration ordinance. Several times they even took matters into their own hands. On one occasion the club sent a committee to interview a delivery man about what they saw as cruelty to his horses. In 1913 they formed a sort of moral vigilante force "to report all those we see smoking cigarettes on the streets." In 1914 they voted to ask "the livery man to take the offensive tobacco signs off of his buildings," and appointed a committee of two (including the elderly Mary Johnson) to discuss this with the offender himself. In a more positive vein, they lobbied for playground space, offered to decorate the school rooms, and donated books and pictures to the school and public library. ${ }^{52}$

Shakespeareans' efforts to raise standards of public behavior may today appear as unwarranted interference with individual morality. However, women's function as moral guardians conformed to the mid-nineteenth-century theory of True Womanhood, and the Shakespeareans' adoption of this role probably gave rise to little public comment, however much private resentment it may have caused. Opposition to tobacco use was a favorite topic of temperance advocates. In Osage, the struggle against alcohol had been effectively won by the WCTU in 1876, when they had successfully lobbied in a municipal election to deny licenses to the four saloons then operating in Osage. ${ }^{53}$

51. Minutes, 2 February 1909, 25 February 1913, Shakespearean Club Archives.

52. Minutes, 6 May and 7 October 1902, 27 January and 3 November 1903, 21 March 1905, 25 October 1910, 9 April 1912, 14 April 1913, 4 April 1914, 30 January 1917, Shakespearean Club Archives. Expectoration not only offended a middle-class sense of decorum; it also created a health hazard in an age when tuberculosis was common among Osage families, irrespective of their social status.

53. Souvenir Booklet: Dedicated to the Women of Mitchell County, Iowa (1892), 29, 35. 
The WCTU then turned its attention to a variety of other topics, including tobacco use, dress reform, animal rights, and, in some groups, woman suffrage..$^{54}$ Opposition to smoking and chewing tobacco had become part of the accepted value system of middleclass women in Osage, and the Shakespeareans were simply taking advantage of their organization and public standing to carry out the role that was expected of them.

Their status as a federated club involved the Shakespeareans in frequent contact with groups outside Osage. Sometimes the Iowa Federation of Women's Clubs contacted them in an attempt to enlist their help. When the Shakespeareans' aid was sought in January 1900 in a movement to promote public libraries in Iowa, the club wrote back promising support. In January 1904 the IFWC's Labor Committee sent a letter asking the Shakespeareans to lobby state representatives in favor of child labor legislation. The club was also an avenue to meetings and conventions; in April 1900, for example, the president (Ella Lapham) went as the club's delegate to the National Congress of Mothers in Des Moines.

The club also donated money to worthy causes, although not indiscriminately. In May 1903 the president of the Oklahoma Federation of Women's Clubs wrote to ask for assistance in building a public library in Atoka. The Shakespeareans responded by sending one dollar. Two years running, they also sent one dollar to the Chicago Woman's Shelter. They were more generous

54. For example, the national WCTU offered prizes for the design of less restrictive women's clothing. WCTU leader Frances Willard stood for a "DoEverything" policy that would expand the WCTU's scope to include suffrage, dress reform, and a number of other causes. More conservative members opposed her approach. Gusfield, Symbolic Crusade, 76, 89-90. In Osage, the 13 August 1891 "Temperance Column" of the Mitchell County Press expressed opposition to "bringing woman suffrage into the W.C.T.U. for the reason that there are many good women in the unions everywhere who do not believe in it. ... [S]ince [Miss Willard] has been meddling in politics the temperance work has suffered." Opposition to tobacco use and support for animal rights appear to have been less controversial in Osage. From an 1884 textbook, Osage public school children learned that tea and coffee, tobacco and opium, along with alcohol, were narcotics "which benumb and stupefy." William Thayer Smith, The Human Body and Its Health (New York, 1884). The 29 October 1891 "Temperance Column" of the Mitchell County Press argued against the use of birds in women's hats. 
with local projects: in 1911 they donated ten dollars to establish a rest room for farm women visiting Osage on market day, and in both 1913 and 1914 they gave ten dollars to the local Scholarship and Loan Fund. When Jeannette Katz brought a destitute family to the club's attention, members voted to send the family $\$ 3.50$ out of money raised by selling Red Cross seals. Foreign causes also won their support; in 1900 they voted that "all money in our treasury be sent for relief" of "suffering India." In 1914, with the onset of war in Europe, they sent a sack of flour to the Belgian relief fund, and the treasurer's report for 1920 shows an expenditure of sixty dollars for "Armenian child support." ${ }^{155}$

Male community leaders generally perceived the Shakespeareans as a force for good. In 1903 school superintendent Jay Lapham (husband of Ella Lapham) wrote in the Osage News of women's clubs' promotion of education reforms. Such clubs, he wrote, were composed of "many of the brightest and best women of our commonwealth." The Shakespeareans had given much time and thought "that they may do their work as to command the respect and cooperation of sensible people throughout this county. ${ }^{156}$ Perhaps this piece was designed to defend the club against detractors. After all, cautions about dangers to women of the "demon of intellect" had appeared in the press only a year before. However, no hint of criticism specifically directed at the Shakespeareans appeared in the contemporary local newspapers, and suggestions were even made that members open their ranks to men, a clear indicator of the club's prestige and success. President Mary Johnson quickly disposed of that idea, however. In her 1898 address at the biennial banquet (to which members invited male friends and relatives), she forecast a dire future for such a mixed-sex group. Addressing the men in the audience, she claimed, "The day we open our doors to you gentlemen, our destruction is sealed.... The first thing you would do, would be to possess yourselves of all of our offices. Not only would you vote for yourselves, but all the

55. Minutes, 8 May 1900, 19 May 1903, 11 April 1911, 21 October and 30 December 1913, 8 and 22 December 1914, 5 December 1916, 23 October 1917, 8 June 1920, Shakespearean Club Archives.

56. Osage News, 23 April 1903. 
women would vote for you." The result would be the silencing of women: "It would be remarked that we did not speak loud enough, became confused, failed to properly point our arguments, lacked valid information on public questions, apt to get excited, lost the thread of discourse, got mad, etc., and after due deliberation a resolution would, no doubt, be passed defining our organs of speech as intended only for the purpose of respiration, mastication and waggin [sic] small talk." ${ }^{157}$ In short, she concluded, "it would be committing club suicide to admit you."

FOR MANY SHAKESPEAREANS at the turn of the century, the club was more than just a study circle. While members never lost sight of the "self-improvement" aspect of their activities, the club also fulfilled a number of other functions. It provided members with a support group of other women in similar circumstances; in addition to the twice-monthly meetings, annual Halloween parties, and biennial banquets, members sent each other wedding gifts, flowers, and letters when family members fell sick or died, congratulations on the birth of new babies, and presented retiring members with specially made spoons. Shakespeareans were also aware of individual members' work for the community and gave each other the public recognition that was otherwise missing in the local newspapers. At the same time, they made demands on each other; in addition to improving themselves as individuals, they realized that the club's reputation and value came from maintaining high group standards of extemporaneous speaking, parliamentary procedure, and pronunciation. By carefully screening potential new members, Shakespeareans ensured that only women they felt were "suitable" would be admitted to the club. In this way, the club served to formalize informal networks already established through kinship, religious affiliation, and occupation. An anomaly like Jeannette Katz was possible largely because her husband was a successful and admired entrepreneur, and because the Katz family adhered to middle-class norms.

57. Osage Sun, 18 May 1898. 
In the first three decades of their club's existence, Shakespeareans carved out a public leadership role for themselves in a variety of ways. While their major activity was always to carry out their fortnightly program, they also developed a number of other strategies that enabled them to influence events and developments in their community, even though direct political involvement was still denied to women. They used the U.S. mail to communicate their ideas and beliefs not only to other women, but to male politicians. They formed committees to approach local politicians, and raised money to support favored causes. They had club activities reported in the newspapers and occasionally submitted the entire contents of a paper delivered at a club meeting to be printed in the local press. They donated books to the public library and suggested changes to the public school curriculum. They did all these things at a time when public sentiment was still skeptical of women's participation in public matters.

The extent to which women like the Shakespeareans succeeded in laying claim to certain areas of the political agenda is striking. To subsequent generations it seems "natural" that women should concern themselves with education, recreational facilities, hygienic surroundings, and pure foods. Women's ownership of these topics was far from natural, however; it was fought for by the active work of women such as the Shakespeareans, but because women were conventionally excluded from the mainstream political arena as well as from most occupations, women's espousal of these reforms was seen as neither work nor politics.

Uncovering the history of clubwomen such as the Shakespeareans may result in a more realistic appreciation of their leadership role and an understanding of their aims and aspirations in their own terms. Such an understanding of club activities may enable us to transcend the unsympathetic stereotypes imposed by contemporaries such as Sinclair Lewis, and instead see these women as participants in community-building efforts that left a lasting impression on small rural towns such as Osage. 
Copyright of Annals of Iowa is the property of State of Iowa, by \& through the State Historical Society of Iowa and its content may not be copied or emailed to multiple sites or posted to a listserv without the copyright holder's express written permission. However, users may print, download, or email articles for individual use. 